\title{
Reviewing audit: barriers and facilitating factors for effective clinical audit
}

\author{
G Johnston, I K Crombie, H T O Davies, E M Alder, A Millard
}

Department of

General Practice, The

Queen's University of

Belfast, Dunluce

Health Centre, Belfast,

UK

G Johnston, lecturer

Department of

Epidemiology and

Public Health,

Ninewells Medical

School, Dundee, UK

I K Crombie, professor

E M Alder, senior lecturer

Department of

Management,

University of St

Andrews, St

Katharine's West, St

Andrews, Fife, UK

H T O Davies, reader

Scottish Clinical Audit Resource Centre,

University of Glasgow,

UK

A Millard, research fellow

Correspondence to:

Dr G Johnston, Department

of General Practice, The

Queen's University of

Belfast, Dunluce Health

Centre, 1 Dunluce Avenue,

Belfast BT9 7HF, UK

Accepted 29 November 1999

\begin{abstract}
Objective-To review the literature on the benefits and disadvantages of clinical and medical audit, and to assess the main facilitators and barriers to conducting the audit process.

Design-A comprehensive literature review was undertaken through a thorough review of Medline and CINAHL databases using the keywords of "audit", "audit of audits", and "evaluation of audits" and a handsearch of the indexes of relevant journals for key papers.

Results-Findings from 93 publications were reviewed. These ranged from single case studies of individual audit projects through retrospective reviews of departmental audit programmes to studies of interface projects between primary and secondary care. The studies reviewed incorporated the experiences of a wide variety of clinicians, from medical consultants to professionals allied to medicine and from those involved in unidisciplinary and multidisciplinary ventures. Perceived benefits of audit included improved communication among colleagues and other professional groups, improved patient care, increased professional satisfaction, and better administration. Some disadvantages of audit were perceived as diminished clinical ownership, fear of litigation, hierarchical and territorial suspicions, and professional isolation. The main barriers to clinical audit can be classified under five main headings. These are lack of resources, lack of expertise or advice in project design and analysis, problems between groups and group members, lack of an overall plan for audit, and organisational impediments. Key facilitating factors to audit were also identified: they included modern medical records systems, effective training, dedicated staff, protected time, structured programmes, and a shared dialogue between purchasers and providers.
\end{abstract}

Conclusions-Clinical audit can be a valuable assistance to any programme which aims to improve the quality of health care and its delivery. Yet without a coherent strategy aimed at nurturing effective audits, valuable opportunities will be lost. Paying careful attention to the professional attitudes highlighted in this review may help audit to deliver on some of its promise.

(Quality in Health Care 2000;9:23-36)

Keywords: audit; attitudes; barriers; facilitating factors
Clinical audit is seen as one approach to improving the quality of patient care. ${ }^{12}$ Its development in the UK was linked to clinicians' desire to improve medical care. ${ }^{2}$ It was thought that, by drawing attention to deficiencies in the delivery of care, this would curb inefficient and ineffective practice. ${ }^{2}$ Clinical audit was introduced throughout the UK NHS in 1990, but the introduction of audit in such a way was untested. Its introduction was based more on faith on what it might achieve ${ }^{3}$ (box 1). There was little evidence to suggest that there would be definite benefits that would justify the scale of the investment. ${ }^{8-11}$

No agreement existed as to which audit methodologies were the most suitable approach and, not surprisingly, there was significant confusion among healthcare professionals about how to implement audit and integrate it effectively into clinical practice. ${ }^{9}{ }^{12}$ There has been a demand for audit programmes to be better evaluated and to be more accountable. ${ }^{910}{ }^{13-15}$ Concerns about the effectiveness of clinical quality improvement activities are not confined to the UK and have been expressed elsewhere in the world-most notably in the United States. ${ }^{16}$

Despite this lack of objective evidence supporting its value, the need for high quality audit has been given fresh impetus through the advent of clinical governance. ${ }^{6}$ The term clinical governance has been recently introduced into the UK NHS to indicate integration of clinical quality improvement with organisational and service performance at all levels. Clinical quality will now be integrated with financial control and service performance at all levels if organisations providing health care are to be managed well. ${ }^{17}$ Hospital chief executives will be personally responsible for the clinical performance of their services. ${ }^{18}$ The centrality of clinical audit in this process is therefore reaffirmed. Clinical audit is now rooted in professional practice within the UK NHS and will be an important aspect of clinical governance. Clinical audit will be central to this process. Indeed, recommendations to facilitate the dissimulation of the concepts of clinical governance into everyday practice seem to reiterate those already advocated for audit. ${ }^{19} 20$ Moreover, it could be argued that audit is one of the few mechanisms with common elements equally applicable to clinical decision making and to organisational efficiency. This suggests that, for clinical governance to achieve the aims of continuous quality improvement, more attention needs to be paid to clinicians' views about audit and to those factors which have been shown both to allow audit to develop and 


\section{The official development of audit in} Britain $^{4}$

1989: white paper, Working for Patients, introduces medical audit. Funding only for doctors $^{5}$

DEFINITIONS OF AUDIT

"the systematic, critical analysis of the quality of medical care, including the procedures used for diagnosis and treatment, the use of resources, and the resulting outcome and quality of life for the patient ${ }^{\prime 5}$

Or

"Audit is the process of reviewing the delivery of care to identify deficiencies so that they may be remedied" 1

1989: area medical audit committees set up as a result of NHS circular 1989 (Gen) 29 to health board general managers

1990: medical audit extended to nurses in response to NHS circular 1990 (Gen) 37 to health board general managers. Setting up of nursing audit committees with funding to be made available from 1991.

Committees followed for dentistry and pharmacy.

1993: clinical audit introduced. In response to NHS circular MEL (1993) 34, area audit committees established to establish audit and agree funding in conjunction with purchasers (boards) and providers (hospitals). All clinicians to be involved.

1997: white paper, The New NHS. Clinical audit given fresh impetus with the introduction of clinical governance ${ }^{6}$

1999: foundation of National Institute of Clinical Excellence and development of National Service Frameworks which provide national standards against which local practice can be assessed $^{7}$

Box 1 Government approaches to quality improvement

those that have been shown to impede its progress.

This article presents a review of the literature evaluating clinical audit. The number of papers reflects the now considerable range of clinical audit activity being undertaken among healthcare professionals. The variety and scope of studies illustrates the gradual evolution of audit from being a specialised activity exclusive only to doctors to one which is much more widespread, encompassing every discipline and every grade. Yet, findings also suggest that the depth of involvement across health care is still uneven - significant activity is still largely confined to enthusiasts.

\section{Aim}

This article seeks to use a comprehensive review of the literature to (a) identify the main advantages and disadvantages of audit and (b) assess the barriers and facilitating factors which either impede or promote successful audit. Much of the literature is from UK studies, although studies from other countries have been included when these provide additional insights. The aim was to determine what recommendations could be made to make clinical audit more effective.

\section{Methods}

A search was conducted of Medline and CINAHL databases for the years 1992-7 using the keywords of "audit", "audit of audits", and "evaluation of audits". Papers which addressed empirical evidence from studies of clinicians' views, and also theoretical discussions, were retrieved and included in this study. The indexes of the BMF, the Lancet, British Fournal of General Practice, Medical Audit News, Quality in Health Care, Audit Trends, and Medical Education were also handsearched for key articles. Each article was carefully read by one of the authors (GJ) and its key findings were identified. The findings were organised into coherent themes using a traditional narrative review approach. This process used a largely qualitative approach and its aim was to identify common elements in the literature which, when integrated, would lead to a greater understanding of the salient issues surrounding clinicians' experiences of undertaking audit. ${ }^{21}$ Key points from each article were collected and classified into broad categories. These categories were then discussed with the remaining authors and refined and synthesised into major themes. No attempt was made to evaluate methodologies or data from the studies retrieved due to their largely disparate and discursive nature. Classification of the main findings is shown in the appendix.

Although this is a comprehensive review the findings are presented in summary form illustrating all the key points which were identified.

\section{Results}

A total of 93 articles were identified. These included discussion papers, government publications, and some papers relating to the same study (appendix). A full bibliography is available from the authors. Studies ranged from single case studies of individual audit projects through retrospective review of departmental audit programmes to studies of interface projects between primary and secondary care. They incorporated the views from a wide variety of clinicians from medical consultants to professionals allied to medicine and from those involved in unidisciplinary and multidisciplinary ventures. The literature review identified 4 main themes:

- Importance of clinicians' perceptions of the benefits of audit

- Importance of clinicians' perceptions of the disadvantages of audit

- Barriers which block its success

- Facilitating factors which promote its success. 
HEALTH PROFESSIONALS' ATTITUDES: BENEFITS OF AUDIT

The perceived benefits of audit can be conveniently discussed under the headings of professional benefits, improvements in patient care, and the quality of service provided.

\section{Professional benefits}

Several studies have reported that clinicians have felt they had benefited from audit through improvements in communication between professional groups and increased professional satisfaction and knowledge. ${ }^{22-26} \mathrm{~A}$ participant observational study of a series of audits of the management of six conditions was conducted in one group practice to understand the factors facilitating change. ${ }^{27}$ The study showed the importance of acknowledging the attitudes of those whose behaviour was being audited and modifying the audit process to accommodate them. Changes in prescribing behaviour were attributed to the fact that doctors were able to control the audit process using their own values and attitudes and that being able to compare one's own practice with that of immediate colleagues and outside authorities provided a powerful impetus to changing behaviour. In addition, audit was seen to promote communication between partners and as a stimulus to learn from colleagues' behaviour.

These additional benefits from audit can increase staff enthusiasm. A pilot study of audit in four professions allied to medicine showed that although there were some constraints to its development there was no evidence of a negative or defeatist attitude to audit. ${ }^{28}$

Patient care and service delivery

Benefits to patient care and service delivery have been commonly identified in audit studies. $^{422}{ }^{29-33}$ A postal survey to explore the attitudes of general practitioners to audit found that $68 \%(n=144)$ of respondents had had experience of audit and $34 \%(n=72)$ claimed to have benefited from it. ${ }^{30}$ Only $28 \%$ reported changes as a result of medical audit, nearly half of which were doctor centred and a quarter patient centred. The patient centred benefits were improvements in patient care, improved patient satisfaction, and better patient feedback. Doctor centred benefits included increased knowledge, satisfaction, performance, and teamwork. Overall, however, attitudes to audit were largely positive and were related to audit experience; the more audit experience the more positive the attitude.

HEALTH PROFESSIONALS' ATTITUDES:

DISADVANTAGES OF AUDIT

Support for audit has not been universal and even those enthusiastic about audit have recognised certain downsides. Sellu has suggested that a key reason why audit has foundered is that doctors have not been convinced that it improves quality. ${ }^{34}$ Perceived disadvantages of audit are diminished clinical ownership, ${ }^{35}$ fear of litigation, ${ }^{36}$ hierarchical and territorial suspicions, ${ }^{37}$ and professional isolation. ${ }^{38}$
Increased workload

Many studies report that clinicians feel that audit detracts from clinical work at the expense of patient care, ${ }^{39} 40$ and that collaboration onlarge projects leads to a reduction and de-skilling of practice based activity. ${ }^{41}$ Consequently, some feel that audit is a waste of time and effort, and that resources would be better spent on patient care. ${ }^{39}{ }^{42}$ Others think it is irrelevant and not part of their job. ${ }^{43}$ Comments from individual clinicians have described audit as an uninspiring but necessary chore, ${ }^{44}$ and "worthy, high minded, useless", or a "fatal flower and with every new blossom it becomes more and more remote from real practice". ${ }^{46}$

\section{Restriction of clinical freedom}

The nature of audit, with its primary aim of improving the quality of care, has important implications for professional conduct. Paradoxically, conflicting perceptions of audit are often evidenced in single studies, highlighting the confusing and often complex issues involved in the way clinicians embrace audit. Although one group practice found many benefits associated with audit, members also perceived it as an external threat and a barrier to providing individualised and the best care possible for patients. ${ }^{27}$ In this study, doctors also expressed a reluctance to criticise each other's behaviour for fear of causing offence, and therefore there was an unwillingness to use clinical standards against which clinical performance could be judged. For these reasons they refused to adopt a practice prescribing policy. Similarly, a study of medical audit in four hospitals found that while $68 \%$ of junior staff surveyed had altered their practice because of audit, consultants were more sceptical and found it difficult to tell whether improvements had stemmed from audit or any other source. ${ }^{38}$ Some consultants were quite definite that it had taught them nothing new.

\section{Professional threat}

It is apparent that while some clinicians are merely unconvinced, others are decidedly hostile to audit. Two large studies of doctors' perceptions of audit have described its negative impact. ${ }^{47}{ }^{48}$ Negative attitudes are associated with suspicion about its motives, fears of intimidation, and ridicule; beliefs that it caused discord among professionals; and a feeling that it was being used as a government ploy to discipline doctors and stifle individuality ${ }^{47}$ Junior doctors in particular saw it in a less positive light than their seniors and described it as threatening, blame apportioning, and a means of professional witch hunting. ${ }^{48}$ Junior doctors have also reported feeling unfairly criticised and alienated while they felt that consultants were not audited rigorously enough. ${ }^{49}$ Many have felt discouraged by the lack of support, direction, and feedback from seniors. ${ }^{50} 51$ These feelings are exacerbated by short term contracts and an inability to see projects to fruition. $^{48}{ }^{52}$ Ironically, consultants have also identified a lack of motivation among junior 
colleagues as important in the failure to achieve meaningful surgical audit. ${ }^{53}$

These negative attitudes are not confined to doctors. They are also perceived by other clinicians as well as dedicated support staff. $^{54} \mathrm{~A}$ study of constraints on the progress of audit experienced by physiotherapists, occupational therapists, speech and language therapists, and clinical psychologists ${ }^{55}$ found that junior therapists in particular felt that audit projects about record keeping were a means of checking up on them. In addition, some feared that the results of audit would lead to a reorganisation of the service and a reduction of their autonomy and even threatened job loss. Important differences in attitude to audit have also been found among different staff groups. ${ }^{56}$

BARRIERS TO SUCCESSFUL AUDIT

Achieving successful audit is not without its difficulties. Given the disparate and divergent views held about audit it is not surprising that there are many perceived barriers to implementing it. In a study of medical audit activity in West Scotland, Kinn and Smith reported a rule of diminishing returns where just half of those involved in audit had completed a project and only half again had repeated a project. ${ }^{43}$ Aprogramme of evaluative projects to review the progress of audit was commissioned by the Department of Health in 1993. Its purpose was to assess the development of audit and its impact on the quality of care, involving a series of interlinked projects each directed at different areas of the medical audit programme in the hospital and community health services in England. ${ }^{22}{ }^{35}$ 57-60 These have shown that the lack of sound methodology used in audit projects resulted in large variations in the approaches taken to audit. ${ }^{61}$ Some critics have argued that, to date, audit has led to "spectacularly" few obvious benefits to patients.

The main barriers to clinical audit can be largely classified under five main headings, following the findings proposed by Robinson ${ }^{62}$ : a lack of resources, lack of expertise or advice in project design and analysis, relationships between groups and group members, lack of an overall plan for audit, and organisational impediments.

\section{Lack of resources}

Numerous studies have described clinicians' common problems about lack of time and dedicated staff ${ }^{4363}$ and inadequate financial and practical resources. ${ }^{64}$ A national study by the National Audit Office for Scotland ${ }^{4}$ found that the major problem which clinicians described was the lack of time to do audit and the resulting conflict between the immediate demands of treating patients and the longer term benefits of audit. Audit facilitators were found to be successful but scarce, so health professionals' time was used inappropriately for tasks which did not use their professional skills. Problems also arose when there was a lack of good quality information systems and information specialists to help clinicians. In addition, there were perceived problems with the financial management of audit funds nationally as well as uncertainty over funding arrangements at a local level. The availability of large amounts of audit funds has also meant that money has sometimes been misappropriated, buying overly complex equipment which staff are not trained to manage. ${ }^{57}$

Lack of expertise in project design and analysis Many studies have reported the obstacles imposed by a lack of expertise in audit methods. These relate to poor design, ${ }^{22}{ }^{48}$ problems with standard setting, ${ }^{65}$ inappropriate and haphazard data collection, ${ }^{26}{ }^{35}$ a shortage of good audit tools, ${ }^{28} 4966$ lack of education and training in audit methods, ${ }^{22} 3552$ and a lack of access to skilled and proactive support staff. ${ }^{35} 4867$

Robinson identified five aspects of undertaking audit projects which required expertise ${ }^{62}$ : writing proposals, specifying and keeping to objectives, designing instruments, analysing data, and writing reports. Sources of guidance specified by those interviewed included colleagues with audit experience, quality assurance staff, dedicated research or audit staff, published work, and audit networks.

However, these difficulties may be compounded by "experts" and support staff who are inadequately trained in audit methods or are too few in number to provide the essential support needed. ${ }^{25867}$ In addition, their contribution and status are often impeded by short term contracts which fail to be renewed when funding has run out. ${ }^{35558}$ One survey of academic departments found that respondents expressed concerns about teaching audit due to a lack of expertise and knowledge in the subject and a worry about how to make it interesting. ${ }^{68}$ A national survey of 382 audit support staff who had registered with an information service found that the majority were women and employed at ancillary and clerical levels. ${ }^{38}$ Seventy one per cent had received training in the basics of audit but $29 \%$ had had no training. The mean length of training was three days. Nearly half of all respondents felt that their training was inadequate or barely adequate. The study also found that audit support staff often felt devalued by medical staff and forced into a delegated role. They therefore found it difficult to take the lead and influence the design of projects and felt they were perceived as glorified secretaries and report writers. On the other hand it has been found that successful audit programmes were those whose leaders had thought carefully about the range of skills the service needed, recognised that the duties of audit staff were not merely clerical, gave training when required, and treated them as valued members of the team. ${ }^{61}$

\section{Lack of an overall plan for audit}

The lack of an overall plan for many audit programmes is reflected in the wide variations in the way audit projects are undertaken and a lack of common vision about their goals and purposes. $^{35585961}$ As a result, their success is often dependent on one enthusiastic leader holding everything together. ${ }^{38}{ }^{57}$ However, it also means that well resourced projects can fail to make an impact because of poor links with 
management, ${ }^{35} 55$ or that projects fail to be completed because support in terms of time and funding have been badly underestimated by participants. ${ }^{22} 3555$ This means that although some resources are available to support projects, others equally necessary for their completion are missing. ${ }^{55}$

\section{Relationship problems}

Dysfunctional group membership or ineffective group dynamics can also impede the success of audit. ${ }^{23}$ Poor relations between and within groups resulting from lack of commitment, a failure to include those being audited, changes in leadership, conflict between staff, concerns about confidentiality, lack of ownership, and a reluctance to change practice have all been found to influence the success of audit. ${ }^{35} 5962$ Studies of interface audit where groups comprise members from both primary and secondary care have also shown that the audit process can be affected by fluctuating membership of the group, lack of clearly defined group tasks, and different professional backgrounds causing mistrust, language barriers, and a lack of knowledge about each others' roles. ${ }^{23}$ In addition, there are logistical problems of finding appropriate and mutually convenient places for meetings ${ }^{69}$ and in holding meetings, even when membership is unidisciplinary, which are not frequently interrupted by telephones, bleeps, and members coming and going. ${ }^{38}$

\section{Organisational impediments}

The absence of a supportive working relationship between clinicians and managers may also impose organisational barriers to audit and the implementation of findings. ${ }^{67} 70$ Studies have shown that there may be disparity between the views of clinicians and management, ${ }^{53} 5971$ and a lack of clarity among clinicians about lines of authority and accountability. ${ }^{2}$ As a result, confusion and inertia often exist among clinicians about who should be responsible for making changes-feelings which increase when changes involve negotiation within the wider hospital. $^{3859}$

A survey of managers and clinicians before the introduction of medical audit reported that although the two groups concurred about the potential advantages of audit, many had different opinions about its disadvantages. ${ }^{39}$ Seventy one per cent of clinicians thought that it would interfere with their clinical workload and $41 \%$ that it would consume resources better spent on patient care. Only one out of eight managers shared clinicians' views, and they were less likely than clinicians to believe that audit would allow them to influence medical practice. Similarly, a study of managers, clinicians, and audit leaders found that while purchasers and providers shared common views on the purpose of clinical audit, there were important differences in their views on the level and appropriateness of involvement of healthcare purchasers. ${ }^{72}$ There were also differences of opinion relating to the sharing of information in the outcomes of clinical audit and changes in behaviour, and in the way audit should be structured and integrated into present NHS processes.

A refusal by managers to make changes on the grounds of cost, and unclear directives from purchasing authorities, also serves to impede the potential of audit to change practice. $^{34}$ In addition, large organisational changes such as hospitals merging or provider units becoming trusts have been shown to delay and disrupt audit activities. ${ }^{22}$

PROMOTING SUCCESSFUL AUDIT

Quantifying success

Attempts to quantify the degree to which audit projects are successful based on the extent to which they complete the audit cycle have been facilitated by the development of classification systems. ${ }^{73-77}$ Several studies have surveyed audit activity using these systems to determine the degree of success of audit activity and the factors associated with it.

One large study of 169 general practitioner practices from which information was available reported that $26 \%$ had completed one full audit and $24 \%$ had not started audit. ${ }^{64}$ Using the Oxford classification system, mean scores were significantly higher with the presence of a practice manager, computerisation, organised notes, being a training practice, and being a partnership. In an earlier study of 80 general practices, $58 \%$ were classified as doing audit and of audits being undertaken, 54\% included planning care or setting standards of care. ${ }^{73}$ However, a review of audits in an ophthalmology department showed that only one of 18 audits reviewed fulfilled the criteria required to qualify for a full audit. ${ }^{26}$

These studies show that audits themselves can and should be monitored with the intention of improving the effectiveness of an audit programme. Paradoxically, they may also suggest that it is likely that those organisations most in need of evaluation and with most potential to improve patient care will be the least likely to establish successful audit programmes. ${ }^{78}$

\section{Factors which promote success}

Despite many obstacles, evaluative studies of medical and clinical audit programmes have helped to define some of the factors which facilitate successful audit. These include the need for practical mechanisms to make data collection easier, including modern medical records systems ${ }^{24}{ }^{64}$; information technology and improved links between routine data collection and audit ${ }^{26}$ as well as dedicated staff; and protected time to release the burden on clinicians' clinical workload. ${ }^{35}{ }^{40}$ From a review of initiatives, Walshe and his colleagues at Caspe identified key factors which promoted the success of audit. ${ }^{57}$ These included a supportive organisational environment, sound leadership and direction of audit programmes, strategy and planning in audit programmes, resources and support for audit programmes, monitoring and reporting of audit activity, commitment and participation, and high levels of audit activity which by its nature and impact 
is seen by its participants to be involving and relevant. The extent to which any or all of these factors are present appears not only to affect whether audit actually takes place, ${ }^{6364}{ }^{79}$ but also determines the degree to which it is successful. ${ }^{59}$ 80-82

Studies of audit in general practice highlight the importance of information technology and support from colleagues in successful audit. A survey of 54 general practices in West Glamorgan assessed the development of records systems and practice organisation and related this to audit activity. ${ }^{83}$ It found that practices with three or more partners and modern medical records systems were more likely to be involved in audit. Audit activity had occurred in $87 \%$ of practices with long term medication summaries and in $87 \%$ which kept clinical summaries and $85 \%$ of practices with age-sex registers. All training practices had undertaken audit compared with only $63 \%$ of non-training practices. Similarly, a Dutch study of 120 general practitioners found that, in addition to financial support, the main requirements for implementing quality assurance programmes and medical audit were regular meetings with colleagues, information on the aims and methods of quality assurance, support in setting up audit and in data collection, and peer review. ${ }^{84}$

\section{Discussion}

THE FUTURE OF AUDIT

This article has identified some of the benefits and some of the difficulties of the implementation of clinical audit and the practical and attitudinal barriers which prevent its progress. At the same time it has drawn attention to some of the main facilitating factors which can make audit work. Although the majority of studies reviewed were largely British and mainly descriptive, evidence from other countries suggests that they are nevertheless applicable to any healthcare programme which is aiming to improve the quality of care. ${ }^{85-88}$

It is clear from this review that audit, and thus clinical governance, faces many obstacles. Furthermore, undertaking it at all requires much commitment and strength of purpose from clinicians. Already there appears to be the same confusion and ambivalence about the implications of clinical governance as there was with the introduction of audit. ${ }^{89} 90$

The barriers which this review has identified need to be addressed systematically. Some of them have been in place for a long time. Without their solution, clinicians faced with growing and conflicting demands on their clinical workload will fail to prioritise audit and, gradually, attempts to incorporate it into their working day will cease. Without the mechanism of clinical audit it is clear that the concept of clinical governance will perish. Some of the key lessons from the studies published to date are highlighted below.

Foster an environment for audit

Recognition should come from a senior level that audit is a valued activity. The benefits to individuals of conducting audit should be more widely broadcast. Audit can augment both career and professional development. High quality audit will be impeded unless time is provided for audit and mechanisms to provide protected time for audit could be developed. Provision of protected time should be accompanied by a commitment from staff to produce a report and to act on the study findings.

Tackle the problems of multidisciplinary audit Multidisciplinary audit can be seen as threatening (exposing one's mistakes to others) and as time wasting and ineffective (designing a study by committee). There is some justification for these views, but action is needed to overcome some of these difficulties. In part this will be achieved by fostering a supportive environment for audit. But it may also need staff training in interpersonal skills and in dealing with conflict. The aim should be to demonstrate to staff that the benefits of engaging in multiprofessional audit outweigh the disadvantages.

\section{Emphasise audit facilitation}

The key role of the audit facilitator needs greater recognition, and hospital audit committees should have an audit programme for facilitators to implement. Hospitals should assess whether additional audit support staff should be employed to provide hands on help and advice on the design of projects.

Audit facilitators need skills in study design, data collection, computing, and statistical analysis and these areas of expertise should be emphasised when appointing new staff. These training needs of facilitators should therefore be explicitly recognised and resources made available to second facilitators to appropriate courses.

\section{Review staff training programmes}

Many of the barriers to successful audit would be overcome by adequate training. The training should emphasise the importance of planning audit carefully and the benefits of conducting a pilot study. As with the audit facilitators, staff training is also needed to deal with conflicts between individuals and between professional groups.

\section{Establish confidentiality of findings}

One of the major concerns of staff is that audit may draw attention to deficiencies in care for which they may be held responsible. This legitimate concern should be addressed and mechanisms put in place to ensure confidentiality and to anonymise the findings.

\section{Ensure all relevant staff are involved}

One of the keys to successful audit is a strong sense of ownership of the study. If staff identify with a study they are much more likely to accept its findings and, where appropriate, implement change. Thus at the start of any project effort should be made to identify the staff groups who might be interested in the findings. Then a representative from each specialty could be invited to join the audit group. 
Establish evaluation programmes

Evaluations of audit programmes such as those undertaken by CASPE need to continue with efforts being focused on the identification of factors at a local level which can promote successful audit. These will help to ensure that the most effective methods are channelled to the most appropriate places. Difficulties such as lack of time, expertise, support, and ineffective information technology systems do not seem insurmountable, but their solution requires more than lip service from those who expect clinicians to undertake audit. Commitment from managers, evidenced by the provision of a structured programme of support and training and the availability of resources to implement realistic changes, may help to persuade those who feel ambivalent and threatened by audit that it can be a useful way of improving the quality of patient care. Without such evidence committed clinicians will fail to sustain their enthusiasm for audit and the more sceptical will not be persuaded that audit is anything more than, at best, a waste of time a professional priority. Clinical audit at its best can be a valuable assistance in delivering such quality. Yet without a coherent strategy aimed at nurturing effective audits, valuable opportunities will be lost. It remains to be seen whether the new ideology of clinical governance can succeed in making audit an accepted and integral part of every clinicians' role. To be effective, clinical governance should pay close attention to the lessons learnt from clinical audit.

\section{Appendix:}

Key findings from the studies uncovered during the literature search

\begin{tabular}{|c|c|c|c|c|c|}
\hline Paper & Subjects/setting & $\begin{array}{l}\text { Advantages identified } \\
\text { or perceived }\end{array}$ & Disadvantages highlighted & $\begin{array}{l}\text { Alleged or perceived barriers } \\
\text { to effective audit }\end{array}$ & $\begin{array}{l}\text { Perceived or reported factors } \\
\text { facilitating effective audit }\end{array}$ \\
\hline $\begin{array}{l}\text { Baker R, Robertson N, Farooqi } \\
\text { A. Audit in general practice: } \\
\text { factors influencing } \\
\text { participation. BMf } \\
\text { 1995;311:31-4 }\end{array}$ & $\begin{array}{l}\text { Interview and } \\
\text { questionnaire survey } \\
\text { of } 147 \text { general } \\
\text { practices invited to } \\
\text { take part in a single } \\
\text { topic audit }\end{array}$ & $\begin{array}{l}\text { Improves care; } \\
\text { Relevant; Valuable; } \\
\text { Essential }\end{array}$ & $\begin{array}{l}\text { Interferes with important } \\
\text { work; Irrelevant }\end{array}$ & $\begin{array}{l}\text { Lack of time and } \\
\text { knowledge; Boring topic; } \\
\text { Already audited topic; } \\
\text { Lack of resources; Lack of } \\
\text { staff; Topic not a priority; } \\
\text { Problems among team; } \\
\text { Changes in partnership; Ill } \\
\text { health of partner; } \\
\text { Previously undertaken an } \\
\text { audit which implemented } \\
\text { change. }\end{array}$ & $\begin{array}{l}\text { Large practice; Partner who } \\
\text { was college member; } \\
\text { Discussion with colleagues; } \\
\text { Positive attitude to audit; } \\
\text { Age of partners; Advisory } \\
\text { group; Training; Financial } \\
\text { help; Administrative } \\
\text { support. }\end{array}$ \\
\hline $\begin{array}{l}\text { Barton A, Spencer J. } \\
\text { Differences in attitudes } \\
\text { towards audit among } \\
\text { specialities in the Northern } \\
\text { Region. Medical Audit News } \\
\text { 1994;4:78-9. }\end{array}$ & $\begin{array}{l}\text { Questionnaire } \\
\text { survey of } 148 \text { senior } \\
\text { undergraduate } \\
\text { clinical tutors in one } \\
\text { university about } \\
\text { their attitude to } \\
\text { audit }\end{array}$ & $\begin{array}{l}\text { Worthwhile; Likely } \\
\text { to produce change; } \\
\text { A way of improving } \\
\text { quality; A core } \\
\text { activity }\end{array}$ & $\begin{array}{l}\text { A waste of time; A fad; } \\
\text { Irrelevant to quality }\end{array}$ & NA & NA \\
\hline $\begin{array}{l}\text { Black N, Thompson E. } \\
\text { Obstacles to medical audit: } \\
\text { British doctors speak. Soc Sci } \\
\text { Med 1993;36:849-56. }\end{array}$ & $\begin{array}{l}\text { Interiews with } 28 \\
\text { consultants and } 34 \\
\text { junior doctors in } 4 \\
\text { district general } \\
\text { hospitals }\end{array}$ & $\begin{array}{l}\text { Good doctoring; } \\
\text { Raises awareness } \\
\text { and problems; } \\
\text { Improves care; } \\
\text { Improves clerical } \\
\text { management }\end{array}$ & $\begin{array}{l}\text { Suspicion about } \\
\text { government's motives; } \\
\text { A means of disciplining } \\
\text { doctors; Junior bashing; } \\
\text { Thwarts individual } \\
\text { patient care; Fear of } \\
\text { conflict/ridicule; Inhibits } \\
\text { criticism; Helps } \\
\text { consultants to get papers }\end{array}$ & $\begin{array}{l}\text { Clinical aspects of care too } \\
\text { difficult to audit; Lack of } \\
\text { peer support/conducive } \\
\text { social environment; Lack } \\
\text { of time; Lack of resources } \\
\text { e.g. secretaries; Extra work } \\
\text { for junior staff; Lack of } \\
\text { knowledge and training in } \\
\text { audit methods; Short } \\
\text { contracts; Lack of } \\
\text { organisation. }\end{array}$ & $\begin{array}{l}\text { Introduction of audit } \\
\text { officers and assistants. }\end{array}$ \\
\hline $\begin{array}{l}\text { Cooper A, French D. } \\
\text { Illustrative examples of } \\
\text { successful audit in General } \\
\text { Practice. Audit Trends } \\
\text { 1993;1:166-9. }\end{array}$ & $\begin{array}{l}\text { A review of Maags } \\
\text { newlsetters and } \\
\text { annual reports }\end{array}$ & $\begin{array}{l}\text { Improvement in } \\
\text { clinical care, } \\
\text { practice } \\
\text { management and } \\
\text { preventive health }\end{array}$ & NA & NA & NA \\
\hline $\begin{array}{l}\text { Chambers R, Bowyer S, } \\
\text { Campbell I. Audit activity } \\
\text { and quality of completed } \\
\text { audit projects in primary } \\
\text { care in Staffordshire. Quality } \\
\text { in Health Care } \\
\text { 1995:4:178-83 }\end{array}$ & $\begin{array}{l}189 \text { General } \\
\text { Practices-visit to } \\
\text { study best audit } \\
\text { project }\end{array}$ & $\begin{array}{l}\text { Educational; } \\
\text { Increased } \\
\text { awareness; } \\
\text { Improved } \\
\text { communication; } \\
\text { Increased teamwork }\end{array}$ & $\begin{array}{l}\text { Modifications made to } \\
\text { tasks, people and } \\
\text { technology. }\end{array}$ & $\begin{array}{l}\text { Lack of resources to make } \\
\text { changes; Uncertainty over } \\
\text { how to proceed with } \\
\text { changes. }\end{array}$ & $\begin{array}{l}\text { Audit enthusiast in team; } \\
\text { Practice manager; Greater } \\
\text { use of computer; Organised } \\
\text { notes; Being a training } \\
\text { practice; Being a } \\
\text { partnership }\end{array}$ \\
\hline $\begin{array}{l}\text { Davies C, Fletcher J, Wilmot J, } \\
\text { et al. Co-ordinated audit in } \\
\text { Warwickshire 1991-1993. } \\
\text { Audit Trends 1995;3:121-6. }\end{array}$ & $\begin{array}{l}53 \text { general practices } \\
(200 \mathrm{GPs}) \text { in one } \\
\text { region }\end{array}$ & $\begin{array}{l}\text { Improved clinical } \\
\text { care; Information } \\
\text { for decision making; } \\
\text { Financial efficiency }\end{array}$ & Managerial tool & $\begin{array}{l}\text { Problems with standard } \\
\text { setting }\end{array}$ & $\begin{array}{l}\text { External reviewer; } \\
\text { Experienced practice in } \\
\text { audit; Good information } \\
\text { systems; Good practice } \\
\text { team work; Interested } \\
\text { people; Staff time; Data } \\
\text { ownership; Product } \\
\text { champion; Linked to main } \\
\text { business }\end{array}$ \\
\hline
\end{tabular}




\begin{tabular}{|c|c|c|c|c|c|}
\hline Paper & Subjects/setting & $\begin{array}{l}\text { Advantages identified } \\
\text { or perceived }\end{array}$ & Disadvantages highlighted & $\begin{array}{l}\text { Alleged or perceived barriers } \\
\text { to effective audit }\end{array}$ & $\begin{array}{l}\text { Perceived or reported factors } \\
\text { facilitating effective audit }\end{array}$ \\
\hline $\begin{array}{l}\text { Davison K, Smith L. Time } \\
\text { spent by doctors on medical } \\
\text { audit. Psychiatric Bulletin } \\
\text { 1993;17:418-19. }\end{array}$ & $\begin{array}{l}\text { Postal survey of } 54 \\
\text { doctors working in } \\
\text { psychiatric units } \\
\text { managed by one } \\
\text { trust }\end{array}$ & Worthwhile & $\begin{array}{l}\text { Spending own time on } \\
\text { audit related activities; } \\
\text { Attendance at audit } \\
\text { meetings at expense of } \\
\text { other activities; Not } \\
\text { worthwhile; Having to } \\
\text { catch up with clinical } \\
\text { work in own time }\end{array}$ & $\begin{array}{l}\text { Lack of dedicated time; } \\
\text { Lack of training }\end{array}$ & $\begin{array}{l}\text { Locally agreed job plans } \\
\text { with dedicated time for } \\
\text { audit; Training days; } \\
\text { Enthusiasm }\end{array}$ \\
\hline $\begin{array}{l}\text { Eccles MP, Hunt J, Newton J. } \\
\text { A case study of an interface } \\
\text { audit group. Audit Trends } \\
\text { 1995;3:127-31. }\end{array}$ & $\begin{array}{l}\text { Case study of one } \\
\text { interface audit } \\
\text { group using } \\
\text { interviews with } 12 \\
\text { members }\end{array}$ & $\begin{array}{l}\text { Satisfaction at being } \\
\text { part of an audit } \\
\text { group; Learning } \\
\text { experience to work } \\
\text { with other } \\
\text { disciplines }\end{array}$ & NA & $\begin{array}{l}\text { Group too big; } \\
\text { Fluctuating membership; } \\
\text { Lack of clearly defined } \\
\text { group task; Medical } \\
\text { hierarchy impeded } \\
\text { members who perceived } \\
\text { themselves as junior; } \\
\text { Different professional } \\
\text { backgrounds; Language } \\
\text { barriers; Different } \\
\text { boundaries; Lack of } \\
\text { knowledge of others' remit }\end{array}$ & NA \\
\hline $\begin{array}{l}\text { Eccles MP, Deverill M, } \\
\text { McColl E, Richardson H. A } \\
\text { national survey of audit } \\
\text { activity across the } \\
\text { primary-secondary care } \\
\text { interface. Quality in Health } \\
\text { Care 1996;5:193-200. }\end{array}$ & $\begin{array}{l}\text { A three phase } \\
\text { national postal } \\
\text { survey using a } \\
\text { cascade sampling } \\
\text { approach }\end{array}$ & $\begin{array}{l}\text { Opportunity for } \\
\text { discussion; Meeting } \\
\text { colleagues from } \\
\text { other disciplines; } \\
\text { Meetings stimulated } \\
\text { learning }\end{array}$ & $\begin{array}{l}\text { Difficult to establish } \\
\text { common goals; } \\
\text { Decisions took longer; } \\
\text { Group disagreements }\end{array}$ & $\begin{array}{l}\text { Incompatible computer } \\
\text { systems; Physical distance } \\
\text { between group members }\end{array}$ & $\begin{array}{l}\text { Commitment; Enthusiasm; } \\
\text { Time; Clear purpose; } \\
\text { Money; Previous knowledge } \\
\text { of a group member; } \\
\text { Common objectives; } \\
\text { Primary-secondary } \\
\text { communication; Adequate } \\
\text { resources and manpower }\end{array}$ \\
\hline $\begin{array}{l}\text { Firth-Cozens J, Storer D. } \\
\text { Registrars' and senior } \\
\text { registrars' perceptions of } \\
\text { their audit activities. Quality } \\
\text { in Health Care 1992;1:161-4. }\end{array}$ & $\begin{array}{l}\text { Postal questionnaire } \\
\text { of } 610 \text { registrars } \\
\text { and senior registrars } \\
\text { in one region }\end{array}$ & $\begin{array}{l}\text { Helps patient care; } \\
\text { Educational }\end{array}$ & $\begin{array}{l}\text { Negative feedback to } \\
\text { juniors; Witch-hunting; } \\
\text { Feeling threatened and } \\
\text { blamed; Consultants not } \\
\text { the subjects of audit; } \\
\text { Reluctance to discuss for } \\
\text { fear of being criticised; } \\
\text { Having to do audit in } \\
\text { own time; Using own } \\
\text { resources }\end{array}$ & $\begin{array}{l}\text { Short term contracts; Lack } \\
\text { of training in audit } \\
\text { methods; Bickering } \\
\text { between consultants; Lack } \\
\text { of time; Lack of resources; } \\
\text { Lack of recognition from } \\
\text { management }\end{array}$ & $\begin{array}{l}\text { Better feedback; More } \\
\text { training; Greater } \\
\text { participation; Dedicated } \\
\text { staff; Expert help; Better } \\
\text { methods; Training; } \\
\text { Computers; Funding; } \\
\text { Action on results; Dedicated } \\
\text { time; Self selection of topic }\end{array}$ \\
\hline $\begin{array}{l}\text { Gabbay J, McNicol MC, Spiby } \\
\text { J, Davies SC, Layton AJ. } \\
\text { What did audit achieve? } \\
\text { Lessons from preliminary } \\
\text { evaluation of a year's } \\
\text { medical audit. BMf } \\
\text { 1990;301:526-9. }\end{array}$ & $\begin{array}{l}\text { Monthly casenote } \\
\text { review. Forty } \\
\text { doctors in one } \\
\text { district general } \\
\text { hospital dealing } \\
\text { with } 140 \text { sets of } \\
\text { notes }\end{array}$ & $\begin{array}{l}\text { Provided forum for } \\
\text { discussion; } \\
\text { Improved general } \\
\text { communication } \\
\text { about clinical } \\
\text { matters between } \\
\text { doctors; Improved } \\
\text { casenotes; Changes } \\
\text { to clinical policy; } \\
\text { Development of } \\
\text { minimum } \\
\text { standards; } \\
\text { Observation } \\
\text { improved practice }\end{array}$ & $\begin{array}{l}\text { Repetitive; Juniors felt } \\
\text { unfairly criticised; } \\
\text { Doubts about } \\
\text { usefulness; Flagging } \\
\text { morale of auditors and } \\
\text { audited; Time and work } \\
\text { spent on audit }\end{array}$ & $\begin{array}{l}\text { Administrative delays in } \\
\text { changing practice; } \\
\text { Differences of opinion } \\
\text { about clinical } \\
\text { management; Thwarted } \\
\text { development of guidelines; } \\
\text { Emphasis on standard of } \\
\text { notes; Detracted from } \\
\text { issues of clinical care; } \\
\text { Logistical problems }\end{array}$ & Support for audit \\
\hline $\begin{array}{l}\text { Gabbay J, Layton AJ. } \\
\text { Evaluation of audit of } \\
\text { medical inpatient records in } \\
\text { a district general hospital. } \\
\text { Quality in Health Care } \\
\text { 1992;1:43-47. }\end{array}$ & $\begin{array}{l}\text { Retrospective } \\
\text { comparison of the } \\
\text { quality of recording } \\
\text { in inpatients' notes }\end{array}$ & $\begin{array}{l}\text { Initial } \\
\text { improvements in } \\
\text { notekeeping }\end{array}$ & $\begin{array}{l}\text { Disaffection; Boredom; } \\
\text { Junior doctors felt audit } \\
\text { being done to them }\end{array}$ & $\begin{array}{l}\text { Lack of feedback to junior } \\
\text { doctors; Lack of } \\
\text { reinforcement from senior } \\
\text { colleagues }\end{array}$ & Lack of audit tools \\
\hline $\begin{array}{l}\text { Grol R, Wensing } M \text {. } \\
\text { Implementation of quality } \\
\text { assurance and medical audit: } \\
\text { general practitioners' } \\
\text { perceived obstacles and } \\
\text { requirements. Br f Gen Pract } \\
\text { 1995;45:548-52. }\end{array}$ & $\begin{array}{l}\text { Interviews with } 120 \\
\text { Dutch general } \\
\text { practitioners }\end{array}$ & NA & NA & $\begin{array}{l}\text { Lack of time; Colleagues' } \\
\text { negative attitudes; Fear of } \\
\text { assessment and criticism; } \\
\text { Lack of knowledge and } \\
\text { skills; Problem in practice } \\
\text { management; No financial } \\
\text { help }\end{array}$ & $\begin{array}{l}\text { Regular meetings; } \\
\text { Information; Data from } \\
\text { other colleagues with which } \\
\text { to compare performance; } \\
\text { Support in data collection }\end{array}$ \\
\hline $\begin{array}{l}\text { Hearnshaw HM, Baker RH, } \\
\text { Robertson N. } \\
\text { Multi-disciplinary audit in } \\
\text { primary health care teams: } \\
\text { facilitation by audit support } \\
\text { staff. Quality in Health Care } \\
\text { 1994;3:164-8. }\end{array}$ & $\begin{array}{l}\text { Case control study } \\
\text { of an audit } \\
\text { facilitator } \\
\text { intervention in } 8 \\
\text { general practices }\end{array}$ & $\begin{array}{l}\text { Increased } \\
\text { teamwork; } \\
\text { Increased } \\
\text { confidence in staff } \\
\text { that standards were } \\
\text { being met; Adoption } \\
\text { of new skills in audit } \\
\text { methods }\end{array}$ & NA & $\begin{array}{l}\text { Illness of team members; } \\
\text { Changes in practice } \\
\text { membership }\end{array}$ & $\begin{array}{l}\text { Team members should } \\
\text { understand and be part of } \\
\text { the process of managing } \\
\text { audit; Stability of group } \\
\text { membership; Willingness of } \\
\text { all members to participate; } \\
\text { External facilitator }\end{array}$ \\
\hline $\begin{array}{l}\text { Johnson R. Where have all the } \\
\text { pennies gone? The work of } \\
\text { Manchester medical audit } \\
\text { advisory group. } B M \mathcal{F} \\
\text { 1994;309:98-102. }\end{array}$ & $\begin{array}{l}\text { Review of the work } \\
\text { of one medical audit } \\
\text { advisory group }\end{array}$ & $\begin{array}{l}\text { Summarising } \\
\text { casenotes; Openness } \\
\text { among doctors } \\
\text { about the work they } \\
\text { do; Improved } \\
\text { teamwork; Standard } \\
\text { setting }\end{array}$ & NA & $\begin{array}{l}\text { Contractual and } \\
\text { organisational changes to } \\
\text { GPs; Increase in amount } \\
\text { of paperwork GPs have to } \\
\text { do }\end{array}$ & $\begin{array}{l}\text { Help in carrying out audit } \\
\text { GPs teaching other GPs; } \\
\text { Staff training; Funding }\end{array}$ \\
\hline
\end{tabular}




\begin{tabular}{|c|c|c|c|c|c|}
\hline Paper & Subjects/setting & $\begin{array}{l}\text { Advantages identified } \\
\text { or perceived }\end{array}$ & Disadvantages highlighted & $\begin{array}{l}\text { Alleged or perceived barriers } \\
\text { to effective audit }\end{array}$ & $\begin{array}{l}\text { Perceived or reported factors } \\
\text { facilitating effective audit }\end{array}$ \\
\hline $\begin{array}{l}\text { Karran SJ, Ranaboldo CJ, } \\
\text { Karran A. Review of the } \\
\text { perceptions of general } \\
\text { surgical staff within the } \\
\text { Wessex region of the status } \\
\text { of quality assurance and } \\
\text { surgical audit. Ann R Coll } \\
\text { Surg Engl 1993;75(Suppl): } \\
\text { 104-7. }\end{array}$ & $\begin{array}{l}\text { Postal survey of } 57 \\
\text { consultant surgeons } \\
\text { and } 48 \text { registrars in } \\
\text { one region }\end{array}$ & $\begin{array}{l}\text { Collection of } \\
\text { clinical outcome } \\
\text { information; Vital; } \\
\text { Useful; Helpful }\end{array}$ & NA & $\begin{array}{l}\text { Lack of time; Lack of } \\
\text { support staff; Lack of } \\
\text { secretarial support; Lack } \\
\text { of commitment }\end{array}$ & NA \\
\hline $\begin{array}{l}\text { Kerrison S, Packwood T, } \\
\text { Buxton M. Medical audit. } \\
\text { Taking stock. London: King's } \\
\text { Fund Centre, 1993: }\end{array}$ & $\begin{array}{l}\text { Case study of audit } \\
\text { activity in four sites }\end{array}$ & $\begin{array}{l}\text { Improves quality of } \\
\text { care; Encourages } \\
\text { efficiency of } \\
\text { resources; } \\
\text { Alterations to } \\
\text { medical practice; } \\
\text { Construction of } \\
\text { local standards; } \\
\text { Educational; } \\
\text { Stimulates debate; } \\
\text { Important } \\
\text { mechanism for } \\
\text { medical } \\
\text { socialisation. Leads } \\
\text { to recommendations } \\
\text { and clarification of } \\
\text { policies }\end{array}$ & $\begin{array}{l}\text { Medical preserve; } \\
\text { Provides an additional } \\
\text { element in medical } \\
\text { management; Makes } \\
\text { little contribution to } \\
\text { wider management; } \\
\text { Dominated by } \\
\text { enthusiasts; Rapidly } \\
\text { implemented; Limited in } \\
\text { scope }\end{array}$ & $\begin{array}{l}\text { Professional isolation; } \\
\text { Logistical problems in } \\
\text { organising groups and } \\
\text { meetings; Lack of } \\
\text { confidence in/access to } \\
\text { audit support staff; } \\
\text { Difficulty in determining } \\
\text { action from results; Lack } \\
\text { of knowledge; Work } \\
\text { pressures; Poor } \\
\text { information sources; Lack } \\
\text { of structure }\end{array}$ & $\begin{array}{l}\text { Ring fenced monies; Audit } \\
\text { committees; Simple design } \\
\text { and analysis; Formal } \\
\text { training; Meeting with } \\
\text { management; Choosing } \\
\text { common problem as topic; } \\
\text { Multi-disciplinary groups; } \\
\text { Committed individuals; IT } \\
\text { support }\end{array}$ \\
\hline $\begin{array}{l}\text { Kinn SR, Smith PJ. Medical } \\
\text { audit activity in primary and } \\
\text { secondary care in the West } \\
\text { of Scotland. Health Bull } \\
\text { 1996;54:252-7. }\end{array}$ & $\begin{array}{l}\text { An anonymised } \\
\text { postal survey of } 150 \\
\text { GPs and } 150 \\
\text { hospital based } \\
\text { clinicians in six } \\
\text { Health Boards }\end{array}$ & $\begin{array}{l}\text { General } \\
\text { improvements; } \\
\text { Useful tool for } \\
\text { bidding for } \\
\text { resources; Patient } \\
\text { benefits }\end{array}$ & $\begin{array}{l}\text { Irrelevant; Too many } \\
\text { trivial audits }\end{array}$ & NA & $\begin{array}{l}\text { Working in a teaching } \\
\text { hospital; Working in a large } \\
\text { general practice; Being } \\
\text { enthusiastic and motivated }\end{array}$ \\
\hline $\begin{array}{l}\text { Lervy B, Wareham K, Cheung } \\
\text { WY. Practice characteristics } \\
\text { associated with audit } \\
\text { activity: a medical audit } \\
\text { advisory group survey. } \mathrm{Br} \mathcal{F} \\
\text { Gen Pract } 1994 ; 44: 311-4 \text {. }\end{array}$ & 57 general practices & NA & NA & NA & $\begin{array}{l}\text { Modern records systems; } \\
\text { Three or more partners; } \\
\text { Clinical summaries; } \\
\text { Training practice }\end{array}$ \\
\hline $\begin{array}{l}\text { Lewis C, Combes D. Is general } \\
\text { practice audit alive and well? } \\
\text { The view from Portsmouth. } \\
\text { Br f Gen Pract } \\
\text { 1996;46:735-6. }\end{array}$ & $\begin{array}{l}82 \text { general practices } \\
\text { in one health } \\
\text { authority }\end{array}$ & NA & $\begin{array}{l}\text { De-skilling of practice } \\
\text { based audit; Time spent } \\
\text { on collaboration }\end{array}$ & NA & $\begin{array}{l}\text { Large practice; } \\
\text { Multi-disciplinary groups; } \\
\text { Audit co-ordinators }\end{array}$ \\
\hline $\begin{array}{l}\text { Lough JM, McKay J and } \\
\text { Murray TS. Audit: trainers' } \\
\text { and trainees' attitudes and } \\
\text { experiences. Med Educ } \\
\text { 1995;29:85-90 }\end{array}$ & $\begin{array}{l}155 \text { GP trainers and } \\
\text { their trainees in } \\
\text { West of Scotland }\end{array}$ & $\begin{array}{l}\text { Useful way of } \\
\text { assessing work; } \\
\text { Improves patient } \\
\text { care }\end{array}$ & $\begin{array}{l}\text { May be used to assess } \\
\text { doctors; Inappropriate } \\
\text { use of time }\end{array}$ & $\begin{array}{l}\text { Lack of time and } \\
\text { resources; Lack of } \\
\text { motivation; Lack of } \\
\text { co-operation from } \\
\text { partners; Lack of } \\
\text { knowledge/training; } \\
\text { Agreeing and setting } \\
\text { standards; Data collection; } \\
\text { Lack of funding; Difficulty } \\
\text { making changes }\end{array}$ & $\begin{array}{l}\text { Protected time; Small group } \\
\text { skills; Training; Database of } \\
\text { current practice; Routine } \\
\text { collection of pre-agreed } \\
\text { data; Agreed protocols; } \\
\text { Support and guidance }\end{array}$ \\
\hline $\begin{array}{l}\text { Lough JM, McKay J, Murray } \\
\text { TS. Audit and summative } \\
\text { assessment: two years pilot } \\
\text { experience. Med Educ } \\
\text { 1995;29:101-103. }\end{array}$ & $\begin{array}{l}117 \text { GP trainees in } \\
\text { West of Scotland }\end{array}$ & $\begin{array}{l}\text { Increased } \\
\text { confidence in } \\
\text { introducing change }\end{array}$ & & $\begin{array}{l}\text { Difficulties with audit } \\
\text { process; Lack of } \\
\text { cooperation from partners } \\
\text { and trainers; Lack of time; } \\
\text { Lack of feedback and } \\
\text { encouragement from } \\
\text { trainers }\end{array}$ & $\begin{array}{l}\text { Support Protected time; } \\
\text { Feedback; Encouragement; } \\
\text { Practical help }\end{array}$ \\
\hline $\begin{array}{l}\text { Millard A. Perceptions of } \\
\text { clinical audit: a preliminary } \\
\text { evaluation. } \mathcal{F} \text { Clin } \\
\text { Effectiveness 1996;1:96-9. }\end{array}$ & $\begin{array}{l}\text { Semi-structured } \\
\text { interviews in four } \\
\text { Scottish Health } \\
\text { Board areas with } 5 \\
\text { audit facilitators, } \\
\text { three clinicians, one } \\
\text { CAMO, one } \\
\text { director of quality, } \\
\text { three national } \\
\text { project coordinators } \\
\text { and three members } \\
\text { of CRAG }\end{array}$ & $\begin{array}{l}\text { Self critical route to } \\
\text { improving patient } \\
\text { care. }\end{array}$ & $\begin{array}{l}\text { Unsystematic; } \\
\text { Threatening. }\end{array}$ & $\begin{array}{l}\text { Lack of awareness of } \\
\text { educational need to do } \\
\text { audit among clinicians; } \\
\text { Short term contracts; } \\
\text { Competitive market where } \\
\text { jobs are at stake; Lack of a } \\
\text { shared understanding of } \\
\text { audit; Lack of } \\
\text { methodological rigour; } \\
\text { Gap between theory and } \\
\text { practice }\end{array}$ & $\begin{array}{l}\text { Collaborative environment; } \\
\text { Clarity of question and } \\
\text { project plan; Systematic } \\
\text { approach; Multi-purpose; } \\
\text { Intention to change } \\
\text { practice; Clinician owned } \\
\text { and driven audit with } \\
\text { feedback; Resource centre; } \\
\text { Expert advice; Central } \\
\text { control and disbursement of } \\
\text { audit funds; Action-based } \\
\text { directives; Requirements for } \\
\text { information set locally; A } \\
\text { national framework for } \\
\text { specialty groups; Overall } \\
\text { plan; Clarity and openness; } \\
\text { Accountability and } \\
\text { evaluation; Promotion of } \\
\text { clinical guidelines; Better } \\
\text { outcomes; Using patients' } \\
\text { views. Sharing good } \\
\text { methods; Pulling specialties; } \\
\text { Growing projects from } \\
\text { national to local. }\end{array}$ \\
\hline
\end{tabular}




\begin{tabular}{|c|c|c|c|c|c|}
\hline Paper & Subjects/setting & $\begin{array}{l}\text { Advantages identified } \\
\text { or perceived }\end{array}$ & Disadvantages highlighted & $\begin{array}{l}\text { Alleged or perceived barriers } \\
\text { to effective audit }\end{array}$ & $\begin{array}{l}\text { Perceived or reported factors } \\
\text { facilitating effective audit }\end{array}$ \\
\hline $\begin{array}{l}\text { Millard A. Health } \\
\text { professionals' needs: audit } \\
\text { reports. Audit Trends } \\
\text { 1996;4:129-132. }\end{array}$ & $\begin{array}{l}34 \text { health } \\
\text { professionals } \\
\text { including nurses } \\
\text { and PAMS in two } \\
\text { Scottish Health } \\
\text { Boards }\end{array}$ & $\begin{array}{l}\text { Local information; } \\
\text { Learning from } \\
\text { others; Ideas from } \\
\text { others on topic } \\
\text { selection and } \\
\text { development; } \\
\text { Information on } \\
\text { better ways of } \\
\text { delivering care; } \\
\text { Information on } \\
\text { audit methods used } \\
\text { by others; } \\
\text { Comparison and } \\
\text { checking of practice; } \\
\text { Collaboration; } \\
\text { Change; Improved } \\
\text { public relations. }\end{array}$ & NA & $\begin{array}{l}\text { Inter professional group } \\
\text { barriers; Suspicion about } \\
\text { the use of audit results; } \\
\text { Lack of time; Lack of } \\
\text { understanding of audit by } \\
\text { managers; Too much } \\
\text { information; Poor audit } \\
\text { methods }\end{array}$ & $\begin{array}{l}\text { Audit facilitators as filters of } \\
\text { information; Audit group } \\
\text { meetings; Education and } \\
\text { training; Reducing the } \\
\text { element of threat }\end{array}$ \\
\hline $\begin{array}{l}\text { Normand C, Ditch J, Dockrell } \\
\text { J, et al. Clinical audit in } \\
\text { professions allied to } \\
\text { medicine and related therapy } \\
\text { professions. Report to the } \\
\text { Department of Health on a } \\
\text { Pilot Study. Belfast: Health } \\
\text { and Healthcare Research } \\
\text { Unit, Queen's University } \\
\text { Belfast, } 1991\end{array}$ & $\begin{array}{l}250 \text { health } \\
\text { professionals from } \\
\text { Clinical Psychology, } \\
\text { Occupational } \\
\text { Therapy, } \\
\text { Physiotherapy and } \\
\text { Speech and } \\
\text { Language Therapy }\end{array}$ & $\begin{array}{l}\text { Improved standards; } \\
\text { Better record } \\
\text { keeping; } \\
\text { Worthwhile; } \\
\text { Recognition of the } \\
\text { need for effective } \\
\text { tools }\end{array}$ & $\begin{array}{l}\text { Administrative burden; } \\
\text { Time directed from } \\
\text { clinical work }\end{array}$ & $\begin{array}{l}\text { Inappropriateness and } \\
\text { poor quality of routinely } \\
\text { available information; } \\
\text { Time involved in } \\
\text { collecting and processing } \\
\text { information; Lack of good } \\
\text { tools to measure outcomes } \\
\text { and quality; Scarcity of } \\
\text { resources; Regrading } \\
\text { exercises }\end{array}$ & $\begin{array}{l}\text { Clerical support; } \\
\text { Recognition of time needed } \\
\text { for audit; A common } \\
\text { framework; Review of } \\
\text { routine information } \\
\text { collected on the activity of } \\
\text { each profession; Dedicated } \\
\text { time; Projects set up to test } \\
\text { and validate existing tools; } \\
\text { National framework }\end{array}$ \\
\hline $\begin{array}{l}\text { National Audit Office. Auditing } \\
\text { clinical care in Scotland. } \\
\text { London: HMSO, } 1994\end{array}$ & $\begin{array}{l}\text { Five health boards } \\
\text { and a selection of } \\
\text { Trusts, provider } \\
\text { units, general } \\
\text { practices and } \\
\text { specialty audit } \\
\text { groups therein and } \\
12 \text { Royal Colleges } \\
\text { interviews and } \\
\text { reports }\end{array}$ & $\begin{array}{l}\text { Changes in clinical } \\
\text { practice, } \\
\text { organisation and } \\
\text { management; } \\
\text { Improved quality of } \\
\text { care; Increased } \\
\text { professional } \\
\text { satisfaction; } \\
\text { Improved cost } \\
\text { effectiveness and } \\
\text { efficiency; Provides } \\
\text { indication of quality } \\
\text { of care being bought } \\
\text { by purchasers }\end{array}$ & $\begin{array}{l}\text { Non-clinicians setting } \\
\text { priorities and making } \\
\text { decisions about funding; } \\
\text { Misinterpretation of } \\
\text { results; Used } \\
\text { inappropriately to } \\
\text { influence purchasing } \\
\text { decisions }\end{array}$ & $\begin{array}{l}\text { Shortage of time; } \\
\text { Problems in the financial } \\
\text { management of funds } \\
\text { nationally; Lack of good } \\
\text { quality clinical } \\
\text { information systems; Lack } \\
\text { of computing skills; } \\
\text { Uncertainty over local } \\
\text { funding arrangements }\end{array}$ & $\begin{array}{l}\text { Disseminate audit } \\
\text { methodologies to National } \\
\text { health Service; Reassess } \\
\text { health professionals' } \\
\text { concerns; Guidance for } \\
\text { purchasers and providers on } \\
\text { the rights and } \\
\text { responsibilities of the health } \\
\text { board; Consider ways to } \\
\text { make clinical information } \\
\text { more available; Purchasers } \\
\text { should discuss audit strategy } \\
\text { with providers before } \\
\text { financial year; Distinguish } \\
\text { how they intend to use } \\
\text { results; Ensure audit } \\
\text { strategy includes reference } \\
\text { to arrangements for } \\
\text { support; Trusts should } \\
\text { provide purchasers with } \\
\text { detailed costed programmes } \\
\text { of audit; Ensure adequate } \\
\text { support staff }\end{array}$ \\
\hline $\begin{array}{l}\text { Penney GC, Templeton A. } \\
\text { Impact of a national audit } \\
\text { project on gynaecologists in } \\
\text { Scotland. Quality in Health } \\
\text { Care } 1995 ; 4: 37-9 \text {. }\end{array}$ & $\begin{array}{l}\text { Postal survey of all } \\
128 \text { consultant } \\
\text { gynaecologists in } \\
\text { Scotland in practice } \\
\text { in } 1994\end{array}$ & $\begin{array}{l}\text { Change in practice; } \\
\text { Reconsider aspects } \\
\text { of practice. }\end{array}$ & NA & NA & $\begin{array}{l}\text { Feedback; Sense of } \\
\text { ownership; Co-operation }\end{array}$ \\
\hline $\begin{array}{l}\text { Pringle M, Bradley C, } \\
\text { Carmichael C, Wallis H, } \\
\text { Moore A. A survey of } \\
\text { attitudes to and experience } \\
\text { of medical audit in General } \\
\text { Practice: Implications for } \\
\text { MAAGS. Audit Trends } \\
\text { 1994;2:9-13. }\end{array}$ & $\begin{array}{l}\text { Postal questionnaire } \\
\text { to } 323 \text { GPs in } \\
\text { Stockport and } \\
\text { Derbyshire }\end{array}$ & $\begin{array}{l}\text { Improvements in } \\
\text { patient care; } \\
\text { Improvements in } \\
\text { patient satisfaction; } \\
\text { Better patient } \\
\text { feedback; Increased } \\
\text { knowledge among } \\
\text { doctors; Increased } \\
\text { awareness; } \\
\text { Increased } \\
\text { satisfaction; } \\
\text { Improved } \\
\text { performance; } \\
\text { Communication } \\
\text { and teamwork; } \\
\text { Better record } \\
\text { keeping; Improved } \\
\text { practice } \\
\text { administration; } \\
\text { Uptake of services; } \\
\text { Personnel } \\
\text { deployment; Reveals } \\
\text { interesting things } \\
\text { about practice; A } \\
\text { good use of time. }\end{array}$ & $\begin{array}{l}\text { Unnecessary; Waste of } \\
\text { time; Boring; } \\
\text { Bureaucratic ploy to } \\
\text { limit clinical freedom }\end{array}$ & NA & $\begin{array}{l}\text { Previous experience of audit } \\
\text { and completing the audit } \\
\text { cycle }\end{array}$ \\
\hline $\begin{array}{l}\text { Robinson S. Audit in the } \\
\text { therapy professions: some } \\
\text { constraints on progress. } \\
\text { Quality in Health Care } \\
\text { 1996;5:206-14. }\end{array}$ & $\begin{array}{l}62 \text { Therapists and } \\
60 \text { stakeholders } \\
\text { including nurses } \\
\text { and doctors, } \\
\text { managers, } \\
\text { purchasers and } \\
\text { quality } \\
\text { co-ordinators }\end{array}$ & $\begin{array}{l}\text { Positive impacts on } \\
\text { the delivery of care, } \\
\text { careers and morale } \\
\text { of therapists }\end{array}$ & NA & $\begin{array}{l}\text { Lack of resources; Lack of } \\
\text { expertise or access to } \\
\text { advice; Relations between } \\
\text { groups; Organizational } \\
\text { structures; Lack of an } \\
\text { overall plan for audit }\end{array}$ & $\begin{array}{l}\text { Time; Support Staff; } \\
\text { Training }\end{array}$ \\
\hline
\end{tabular}




\begin{tabular}{|c|c|c|c|c|c|}
\hline Paper & Subjects/setting & $\begin{array}{l}\text { Advantages identified } \\
\text { or perceived }\end{array}$ & Disadvantages highlighted & $\begin{array}{l}\text { Alleged or perceived barriers } \\
\text { to effective audit }\end{array}$ & $\begin{array}{l}\text { Perceived or reported factors } \\
\text { facilitating effective audit }\end{array}$ \\
\hline $\begin{array}{l}\text { Robinson S. Evaluating the } \\
\text { progress of clinical audit. Int } \\
\text { f Theory, Research and } \\
\text { Practice 1996;2:373-92. }\end{array}$ & $\begin{array}{l}62 \text { Therapists and } \\
60 \text { stakeholders } \\
\text { including nurses } \\
\text { and doctors, } \\
\text { managers, } \\
\text { purchasers and } \\
\text { quality } \\
\text { co-ordinators }\end{array}$ & $\begin{array}{l}\text { Professional } \\
\text { confidence; } \\
\text { Understanding of } \\
\text { each other's role; } \\
\text { Good for C.V.; } \\
\text { Improved patient } \\
\text { care; Enhanced } \\
\text { accountability; } \\
\text { Greater ability to } \\
\text { complement each } \\
\text { other's roles; } \\
\text { Decreased } \\
\text { professional } \\
\text { marginalisation; } \\
\text { Raised morale }\end{array}$ & $\begin{array}{l}\text { Intimidation of junior } \\
\text { staff; Fear of losing job; } \\
\text { Loss of autonomy; } \\
\text { Highlighted limitations; } \\
\text { Unfair; Disheartening; } \\
\text { Time spent on } \\
\text { paperwork }\end{array}$ & $\begin{array}{l}\text { Poor project planning; } \\
\text { Lack of training; Poor } \\
\text { relationships with } \\
\text { management }\end{array}$ & NA \\
\hline $\begin{array}{l}\text { Russell IT, et al. Medical audit } \\
\text { in general practice. I: Effects } \\
\text { on doctors' clinical } \\
\text { behaviour for common } \\
\text { childhood conditions. BMF } \\
\text { 1992;304:1480-4. }\end{array}$ & $\begin{array}{l}\text { Study of the impact } \\
\text { of } 4 \text { different types } \\
\text { of medical audit on } \\
\text { the behaviour of } 92 \\
\text { general practitioner } \\
\text { trainers for five } \\
\text { conditions. Before } \\
\text { and after } \\
\text { comparison. }\end{array}$ & $\begin{array}{l}\text { Change and } \\
\text { improvements in } \\
\text { prescribing practice; } \\
\text { Improved follow up. }\end{array}$ & NA & Changes in partnership. & $\begin{array}{l}\text { Setting own standards; } \\
\text { Medical records } \\
\text { enhancement forms }\end{array}$ \\
\hline $\begin{array}{l}\text { Smith HE, Russell GI, Frew } \\
\text { AJ, et al. Medical audit: the } \\
\text { differing perspectives of } \\
\text { managers and clinicians. J R } \\
\text { Coll Physicians Lond } \\
\text { 1992;26:177-80. }\end{array}$ & $\begin{array}{l}\text { A questionnaire } \\
\text { survey of } 144 \\
\text { clinicians and } 70 \\
\text { managers in one } \\
\text { health district about } \\
\text { their perceptions of } \\
\text { audit before its } \\
\text { introduction }\end{array}$ & $\begin{array}{l}\text { Would improve the } \\
\text { quality of patient } \\
\text { care; Would be an } \\
\text { important } \\
\text { component of } \\
\text { continuing medical } \\
\text { education; } \\
\text { Worthwhile; A } \\
\text { means of } \\
\text { maintaining } \\
\text { professional } \\
\text { freedom by } \\
\text { demonstrating } \\
\text { proficiency }\end{array}$ & $\begin{array}{l}\text { Interference with routine } \\
\text { clinical workload; Waste } \\
\text { of effort; Will utilise } \\
\text { resources more } \\
\text { important for patient } \\
\text { care; Would allow } \\
\text { mangers to manipulate } \\
\text { clinical practice; Restrict } \\
\text { clinical activity; Lack of } \\
\text { objective evidence }\end{array}$ & Lack of time & NA \\
\hline $\begin{array}{l}\text { Spencer JA. Audit and } \\
\text { academic departments of } \\
\text { general practice: a survey in } \\
\text { the United Kingdom and } \\
\text { Eire. Br f Gen Pract } \\
\text { 1992;42:333-5. }\end{array}$ & $\begin{array}{l}\text { A questionnaire and } \\
\text { telephone survey of } \\
31 \text { academic } \\
\text { departments of } \\
\text { General Practice in } \\
\text { Britain and Eire } \\
\text { about problems in } \\
\text { teaching medical } \\
\text { audit }\end{array}$ & NA & $\begin{array}{l}\text { Time spent on audit; } \\
\text { Not auditing own work }\end{array}$ & $\begin{array}{l}\text { Lack of time; Difficulty } \\
\text { making topic interesting } \\
\text { and relevant; Negative } \\
\text { attitudes from colleagues }\end{array}$ & NA \\
\hline $\begin{array}{l}\text { Tabendeh H, Thompson GM. } \\
\text { Auditing ophthalmology } \\
\text { audits. Eye } \\
\text { 1995;9(Suppl):1-5. }\end{array}$ & $\begin{array}{l}\text { Evaluation of one } \\
\text { departmental audit } \\
\text { programme }\end{array}$ & $\begin{array}{l}\text { Educational; } \\
\text { Baseline } \\
\text { information; } \\
\text { Improved patient } \\
\text { care; Effect on } \\
\text { practice }\end{array}$ & $\begin{array}{l}\text { Time consuming; } \\
\text { Boring. }\end{array}$ & $\begin{array}{l}\text { Data collection; Poor } \\
\text { planning. }\end{array}$ & $\begin{array}{l}\text { Education and training; } \\
\text { Careful choice of topic; Link } \\
\text { between routine data } \\
\text { systems and audit; } \\
\text { Prospective data collection; } \\
\text { Development of databases; } \\
\text { College guidance; Clear } \\
\text { plan; Re-evaluation. }\end{array}$ \\
\hline $\begin{array}{l}\text { Thomson R, Elcoat C, Pugh E. } \\
\text { Clinical audit and the } \\
\text { purchaser-provider } \\
\text { interaction: different } \\
\text { attitudes and expectations in } \\
\text { the United Kingdom. } \\
\text { Quality in Health Care } \\
\text { 1996;5:97-103. }\end{array}$ & $\begin{array}{l}\text { Interviews with } \\
\text { chief executives, } \\
\text { contracts managers, } \\
\text { quality audit } \\
\text { leaders, directors of } \\
\text { public health, } \\
\text { consultants, GPs, } \\
\text { audit support staff } \\
\text { and practice } \\
\text { managers }\end{array}$ & $\begin{array}{l}\text { Measures and } \\
\text { improves the quality } \\
\text { of care; Evaluates } \\
\text { practice; Produces } \\
\text { outcomes; } \\
\text { Educational; Results } \\
\text { in change; Provides } \\
\text { purchasers with } \\
\text { provider } \\
\text { performance data; } \\
\text { Questions practice }\end{array}$ & $\begin{array}{l}\text { Causes resentment } \\
\text { among providers; } \\
\text { Diminishes clinical } \\
\text { ownership; Lack of } \\
\text { confidentiality; Little } \\
\text { outcome on local } \\
\text { purchasing decisions; } \\
\text { Punitive to providers }\end{array}$ & $\begin{array}{l}\text { Reluctance to share } \\
\text { information; Lack of } \\
\text { knowledge of purchasers } \\
\text { re clinical practice may } \\
\text { lead to inappropriate } \\
\text { comparisons }\end{array}$ & $\begin{array}{l}\text { Mutual dialogue between } \\
\text { purchasers and providers; } \\
\text { Common understanding; } \\
\text { Dedicated staff; Information } \\
\text { technology; Money; } \\
\text { Protected time; Realistic } \\
\text { expectations }\end{array}$ \\
\hline $\begin{array}{l}\text { Toy PTCY. Effectiveness of } \\
\text { transfusion audits and } \\
\text { practice guidelines. Arch } \\
\text { Path Lab Med 1994; } \\
\text { 118:435-437 }\end{array}$ & $\begin{array}{l}\text { Literature review of } \\
\text { published data } \\
\text { which attested to } \\
\text { the effectiveness of } \\
\text { transfusion audits. }\end{array}$ & $\begin{array}{l}\text { Improvements in } \\
\text { practice; Guidelines; } \\
\text { Education of } \\
\text { technologists }\end{array}$ & NA & NA & Education \\
\hline $\begin{array}{l}\text { Watkins CJ, King J. } \\
\text { Understanding the barriers } \\
\text { to medical audit: insights } \\
\text { from the experience of one } \\
\text { practice. Audit Trends } \\
1996 ; 4: 47-52 \text {. }\end{array}$ & $\begin{array}{l}\text { Participant } \\
\text { observational study } \\
\text { in one } 7 \text { partner } \\
\text { group practice }\end{array}$ & $\begin{array}{l}\text { Potent tool for } \\
\text { understanding } \\
\text { decision making in } \\
\text { the consulting } \\
\text { room; Facilitates } \\
\text { communication and } \\
\text { understanding } \\
\text { between partners in } \\
\text { practice; Changes in } \\
\text { practice prescribing } \\
\text { policy. }\end{array}$ & $\begin{array}{l}\text { Impedes individualised } \\
\text { care; External threat; } \\
\text { Reluctance to criticise } \\
\text { colleagues; Threat to } \\
\text { freedom }\end{array}$ & $\begin{array}{l}\text { The presence of an } \\
\text { enthusiast prohibited the } \\
\text { development of } \\
\text { colleagues' skills and } \\
\text { excluded them from the } \\
\text { audit activity }\end{array}$ & $\begin{array}{l}\text { Preserving confidentiality; } \\
\text { Anonymising data; } \\
\text { Objective outside sources of } \\
\text { information }\end{array}$ \\
\hline $\begin{array}{l}\text { Webb SJ, Dowell AC, } \\
\text { Heywood P. Survey of } \\
\text { general practice audit in } \\
\text { Leeds. BMF } \\
\text { 1991;302:390-2. }\end{array}$ & $\begin{array}{l}\text { Postal survey of } 386 \\
\text { GPs }\end{array}$ & NA & NA & $\begin{array}{l}\text { Lack of time; Size of task; } \\
\text { Lack of knowledge of and } \\
\text { training in audit methods; } \\
\text { Lack of cooperation from } \\
\text { other colleagues; } \\
\text { Resources }\end{array}$ & $\begin{array}{l}\text { Modern records systems; } \\
\text { Training; Time; Support; } \\
\text { Strategy for General } \\
\text { Practice; Co-operation from } \\
\text { FHAs, MAAGS and } \\
\text { government }\end{array}$ \\
\hline
\end{tabular}




\begin{tabular}{|c|c|c|c|c|c|}
\hline Paper & Subjects/setting & $\begin{array}{l}\text { Advantages identified } \\
\text { or perceived }\end{array}$ & Disadvantages highlighted & $\begin{array}{l}\text { Alleged or perceived barriers } \\
\text { to effective audit }\end{array}$ & $\begin{array}{l}\text { Perceived or reported factors } \\
\text { facilitating effective audit }\end{array}$ \\
\hline $\begin{array}{l}\text { Webb MD, Harvey IM. Taking } \\
\text { stock of medical audit: a } \\
\text { questionnaire survey. } \\
\text { Medical Audit News } \\
\text { 1992;2:18. }\end{array}$ & $\begin{array}{l}\text { Postal survey of } 140 \\
\text { consultants in one } \\
\text { health authority }\end{array}$ & $\begin{array}{l}\text { Improves } \\
\text { performance; } \\
\text { Educational }\end{array}$ & $\begin{array}{l}\text { Unnecessary because } \\
\text { medical practice is } \\
\text { self-auditing }\end{array}$ & $\begin{array}{l}\text { Fear of litigation; Lack of } \\
\text { clerical support; Lack of } \\
\text { time; Lack of computers; } \\
\text { Lack of finance; Lack of } \\
\text { clinician involvement; } \\
\text { Lack of education and } \\
\text { training in audit methods. }\end{array}$ & NA \\
\hline $\begin{array}{l}\text { Webb MD, Harvey IM. } \\
\text { Auditing the Introduction of } \\
\text { Audit. Medical Audit News } \\
\text { 1994;4:19-20. }\end{array}$ & $\begin{array}{l}\text { Postal questionnaire } \\
\text { to } 147 \text { consultants } \\
\text { in one health } \\
\text { authority }\end{array}$ & $\begin{array}{l}\text { Change in clinical } \\
\text { practice e.g. changes } \\
\text { in treatment, setting } \\
\text { up of new clinic, } \\
\text { policy changes }\end{array}$ & $\begin{array}{l}\text { Time spent on } \\
\text { inappropriate tasks; } \\
\text { Cost }\end{array}$ & $\begin{array}{l}\text { Pressure of clinical work; } \\
\text { Lack of clerical support or } \\
\text { audit administrators Lack } \\
\text { of financial support from } \\
\text { management to effect } \\
\text { change; Lack of } \\
\text { confidence in audit } \\
\text { committees }\end{array}$ & $\begin{array}{l}\text { Audit administrators; Time; } \\
\text { Clerical support }\end{array}$ \\
\hline \multicolumn{6}{|l|}{ CASPE Evaluations * } \\
\hline $\begin{array}{l}\text { Amess M, Walshe K, Shaw } \\
\text { C and Coles J. The audit } \\
\text { activities of the medical } \\
\text { Royal Colleges and their } \\
\text { Faculties in England, } 1995\end{array}$ & $\begin{array}{l}\text { Document review } \\
\text { and semistructured } \\
\text { interviews with } \\
\text { audit representative } \\
\text { from } 11 \text { Royal } \\
\text { Colleges in England }\end{array}$ & $\begin{array}{l}\text { Mechanism for } \\
\text { change; Quality } \\
\text { accreditation; } \\
\text { Change in attitude } \\
\text { towards audit; } \\
\text { Establishment of } \\
\text { audit departments }\end{array}$ & $\begin{array}{l}\text { Resistance to change; } \\
\text { Doubt about its value; } \\
\text { Threatening }\end{array}$ & $\begin{array}{l}\text { Confusion about role of } \\
\text { colleges in audit; Lack of } \\
\text { direction; Fragmented } \\
\text { approach; Isolation from } \\
\text { practice; Short term } \\
\text { funding; Medical } \\
\text { dominance; Lack of } \\
\text { evaluation of audit; } \\
\text { programmes; Lack of } \\
\text { training; Lack of reporting } \\
\text { mechanisms }\end{array}$ & $\begin{array}{l}\text { Dissemination of } \\
\text { information; Long term } \\
\text { funding; Clarification of } \\
\text { role; Enhanced educational } \\
\text { role; Collaboration with } \\
\text { non-medical personnel }\end{array}$ \\
\hline $\begin{array}{l}\text { Bennett J and Coles J Brighton } \\
\text { Health Care NHS Trust's } \\
\text { clinical audit programme. } \\
\text { 1996; Rumsey M Buttery Y } \\
\text { Bennett J and Cole J North } \\
\text { Staffordshire's joint clinical } \\
\text { audit programme 1996; } \\
\text { Buttery, Y, Rumsey M, } \\
\text { Bennett J and Coles J Dorset } \\
\text { Healthcare NHS Trusts } \\
\text { Clinical Audit Programme } \\
\text { 1995; Rumsey M, Buttery Y, } \\
\text { Bennett J and Coles J } \\
\text { Wythenshawe Hospital's } \\
\text { clinical audit programme A } \\
\text { case study 1996; Buttery Y, } \\
\text { Walshe K, Rumsey M, } \\
\text { Bennett J and Coles J. A } \\
\text { review of } 29 \text { programmes } \\
1995\end{array}$ & $\begin{array}{l}\text { A review of } 29 \text { audit } \\
\text { programmes } \\
\text { including } 4 \text { case } \\
\text { studies }\end{array}$ & $\begin{array}{l}\text { Greater } \\
\text { interprofessional } \\
\text { communication; } \\
\text { Better } \\
\text { understanding of } \\
\text { each others' roles; } \\
\text { More } \\
\text { patient-centred } \\
\text { approach; More } \\
\text { effective audit; } \\
\text { Improved quality of } \\
\text { healthcare; Changes } \\
\text { in clinical practice; } \\
\text { Changes in service } \\
\text { delivery; Changes in } \\
\text { organisational } \\
\text { structure; Quality } \\
\text { management } \\
\text { systems; } \\
\text { Worthwhile; Good } \\
\text { investment }\end{array}$ & $\begin{array}{l}\text { Reduced confidentiality } \\
\text { of process; Harder to } \\
\text { speak frankly and } \\
\text { openly; Concerns of } \\
\text { other professionals } \\
\text { uninteresting; Different } \\
\text { approaches and } \\
\text { methods; Meetings too } \\
\text { large and unmanageable; } \\
\text { Medical staff expect to } \\
\text { lead process; Differences } \\
\text { in status and power; } \\
\text { Suspicion about } \\
\text { managerial involvement }\end{array}$ & $\begin{array}{l}\text { Topics individually } \\
\text { determined; Not part of } \\
\text { core business; Professional } \\
\text { distance; Inegalitarian } \\
\text { funding; Confusion; } \\
\text { Overlap and duplication of } \\
\text { effort; Territorial tension; } \\
\text { Bad organisation; No } \\
\text { audit strategy; Poor links } \\
\text { between audit and } \\
\text { education; Variations in } \\
\text { leadership and size of } \\
\text { audit committees; } \\
\text { Confusion over role of } \\
\text { audit support staff; Lack } \\
\text { of organisation and skill } \\
\text { mix among support staff; } \\
\text { Lack of basic IT systems } \\
\text { or purchase of complex } \\
\text { systems; Lack of training } \\
\text { in audit methods; } \\
\text { Incomplete or unfocused } \\
\text { data collection; Lack of } \\
\text { effective monitoring } \\
\text { strategies; Different } \\
\text { attitudes; Differential } \\
\text { benefits; Lack of selection } \\
\text { and prioritisation of audit } \\
\text { topics; Late involvement } \\
\text { of managers and lack of } \\
\text { ownership of audit activity }\end{array}$ & $\begin{array}{l}\text { Organisational environment; } \\
\text { Leadership and direction of } \\
\text { audit programmes; Strategy } \\
\text { and planning in audit } \\
\text { programmes; Resources and } \\
\text { support for audit } \\
\text { programmes; Monitoring } \\
\text { and reporting of audit } \\
\text { activity; Commitment and } \\
\text { participation; Nature of } \\
\text { audit activity; Wide impact } \\
\text { of audit }\end{array}$ \\
\hline $\begin{array}{l}\text { Foster J, Willmot } M \text { and Coles } \\
\text { J. Nursing and therapy audit. } \\
\text { An evaluation of twenty-four } \\
\text { projects and initiatives }\end{array}$ & $\begin{array}{l}\text { Site visits to a } \\
\text { sample of provider } \\
\text { units hosting audit } \\
\text { activity identified by } \\
\text { a previous survey } \\
\text { (Willmot et al, } \\
\text { 1995) }\end{array}$ & $\begin{array}{l}\text { Improved } \\
\text { professional } \\
\text { communication; } \\
\text { Changes to patient } \\
\text { care; Raised } \\
\text { awareness of audit } \\
\text { subject; Cost } \\
\text { effective; Raised } \\
\text { profile of audit; } \\
\text { Development of } \\
\text { guidelines }\end{array}$ & NA & $\begin{array}{l}\text { Lack of skill in audit } \\
\text { methods; Ambiguity about } \\
\text { the difference between } \\
\text { audit and research; Lack } \\
\text { of direction or clarity to } \\
\text { project; Difficulties in } \\
\text { arranging } \\
\text { multi-disciplinary } \\
\text { meetings over large } \\
\text { geographical area; Lack of } \\
\text { dedicated time; } \\
\text { Professional discontinuity; } \\
\text { Isolation of groups; Lack } \\
\text { of involvement of those } \\
\text { being audited; Lack of } \\
\text { ownership }\end{array}$ & $\begin{array}{l}\text { Organisational environment; } \\
\text { Consistent and clear } \\
\text { leadership; Education and } \\
\text { expertise; Clear aims and } \\
\text { objectives; Involvement of } \\
\text { clinicians; Clear impact }\end{array}$ \\
\hline $\begin{array}{l}\text { Walshe } \mathrm{K} \text { and Coles } \mathrm{J} \text {. } \\
\text { Evaluating audit a review of } \\
\text { initiatives }\end{array}$ & $\begin{array}{l}\text { Study of } 20 \\
\text { initiatives to } \\
\text { evaluate audit using } \\
\text { a literature review } \\
\text { and survey }\end{array}$ & NA & NA & $\begin{array}{l}\text { Few tools for evaluation } \\
\text { exist; Little evaluation } \\
\text { takes place; Predominance } \\
\text { of provider-clinician } \\
\text { perspective in evaluation; } \\
\text { Little evaluation above } \\
\text { provider unit takes place; } \\
\text { Little knowledge of audit } \\
\text { activity across NHS exists; } \\
\text { Little knowledge of the } \\
\text { costs and benefits; Limited } \\
\text { involvement in evaluation } \\
\text { at regional level }\end{array}$ & $\begin{array}{l}\text { Development of tools; More } \\
\text { evaluations of clinical audit } \\
\text { and from the perspectives of } \\
\text { purchasers, providers and } \\
\text { patients; Evaluations of } \\
\text { audit programmes; } \\
\text { Evaluation of audit across } \\
\text { NHS; Evaluation of cost } \\
\text { effectiveness }\end{array}$ \\
\hline
\end{tabular}




\begin{tabular}{|c|c|c|c|c|c|}
\hline Paper & Subjects/setting & $\begin{array}{l}\text { Advantages identified } \\
\text { or perceived }\end{array}$ & Disadvantages highlighted & $\begin{array}{l}\text { Alleged or perceived barriers } \\
\text { to effective audit }\end{array}$ & $\begin{array}{l}\text { Perceived or reported factors } \\
\text { facilitating effective audit }\end{array}$ \\
\hline $\begin{array}{l}\text { Willmot } \mathrm{M} \text {, Foster J, Walshe } \mathrm{K} \\
\text { and Coles J. A review of } \\
\text { audit activity in the nursing } \\
\text { and therapy professions }\end{array}$ & $\begin{array}{l}\text { A national postal } \\
\text { survey of recipients } \\
\text { of nursing and } \\
\text { therapy audit } \\
\text { funding in the } 14 \\
\text { regional health } \\
\text { authorities in } \\
\text { England }\end{array}$ & $\begin{array}{l}\text { Changes in } \\
\text { knowledge and } \\
\text { awareness; Changes } \\
\text { in communication } \\
\text { with clinicians or } \\
\text { patients; Changes in } \\
\text { clinical } \\
\text { management; } \\
\text { Changes in record } \\
\text { keeping/ } \\
\text { documentation; } \\
\text { Development and } \\
\text { implementation of } \\
\text { guidelines and } \\
\text { standards; Changes } \\
\text { in culture and } \\
\text { attitudes; New } \\
\text { services; Changes in } \\
\text { availability of } \\
\text { training and } \\
\text { education; Change } \\
\text { in access to/cost of } \\
\text { healthcare; Changes } \\
\text { in prescribing }\end{array}$ & NA & $\begin{array}{l}\text { Lack of resources; Lack of } \\
\text { acceptance and } \\
\text { commitment by staff poor } \\
\text { project planning; Lack of } \\
\text { experience in audit; } \\
\text { Changes in structure or } \\
\text { management; Small } \\
\text { projects; Lack of strategy } \\
\text { or business plan }\end{array}$ & $\begin{array}{l}\text { Co-operation and } \\
\text { commitment from staff; } \\
\text { Good organisation and } \\
\text { teamwork; An efficient audit } \\
\text { department and facilitator; } \\
\text { Appropriate information } \\
\text { technology; Training in } \\
\text { audit techniques; Raised } \\
\text { awareness of audit activity } \\
\text { e.g. posters, newsletters; } \\
\text { Information }\end{array}$ \\
\hline
\end{tabular}

The literature cited under each of these headings is not exhaustive, but instead studies have been chosen to illustrate key points.

^The CASPE publications can be purchased from CASPE Research, 22 Palace Court, Bayswater, London W2 4HU.

1 Crombie I, Davies H, Abraham S, et al. The audit handbook: improving health care through clinical audit. Chichester: John Wiley \& Sons, 1993

2 Hopkins A. Clinical audit: time for reappraisal? $\mathcal{f} R$ Coll Physicians Lond 1996;30:415-25.

3 Barton A, Thompson R, Bhopal R. Clinical audit: more research is required. $f$ Epidemiol Community Health

4 National Audit Office. Auditing clinical care in Scotland. London: HMSO, 1994

5 Department of Health. Working for patients. London: HMSO, 1989.

6 Department of Health. The new NHS. London: The Stationary Office, 1997

7 Rawlins M. National health service: in pursuit of quality: the National Institute for Clinical Excellence. Lancet 1999;353 1079-82.

8 Walshe K, editor. Introduction. Evaluating clinical audit; past lessons, future directions. London: The Royal Society of Medicine Press, 1995.

9 Miles A, Bentley P, Polychronis A, et al. Clinical audit in the National Health Service: fact or fiction? Fournal of Evaluation in Clinical Practice $1996 ; 2: 29-35$.

10 Buxton MJ. Achievements of audit in the NHS. Quality in Health Care 1994;3(suppl):s31-4.

11 Robinson MB. Evaluation of medical audit. $f$ Epidemiol Community Health 1994;48:435-40.

12 Nolan M, Scott G. Audit: an exploration of some tensions and paradoxical expectations. F Adv Nurs 1993;18:759-66.

13 Maynard A. Case for auditing audit. Health Service fournal 1991;101:26.

14 Mooney G, Ryan M. Rethinking medical audit: the goal is efficiency. F Epidemiol Community Health 1992;46:180-3.

15 Fulton R. Goals and methods of audit should be reappraised. BMF 1996;312:1103.

16 Shortell S, Bennett CL Byck GR. Assessing the continuous quality improvement on clinical practice: what it will take
to accelerate progress. Millbank Quarterly 1998;76:593to acce.

17 Scally G, Donaldson L. Clinical governance and the drive for quality improvement in the new NHS in England. $B M Y$ 1998;317:61-5.

18 Black N. Clinical governance: fine words or action? $B M \mathcal{F}$ 1998;316:297-8.

19 Smith LFP, Harris D. Clinical governance-a new label for old ingredients: quality or quantity. $\mathrm{Br} \mathcal{F} \mathrm{Gen}$ Pract 1999;49:339-40

20 Donaldson LJ, Gray JAM. Clinical governance: a quality duty for health organisations. Quality in Health Care 1998; 7(suppl):s37-44.

21 Strauss A, Corbin J. Basics of qualitative research. Grounded theory procedures and techniques. Newbury Park, CA: Sage Publications, 1990.

22 Willmot $\mathrm{M}$, Foster J, Walshe $\mathrm{K}$, et al. A review of audit activity in the nursing and therapy professions. Findings of a national survey. London: Caspe Research, 1995

23 Eccles MP, Hunt J, Newton J. A case study of an interface audit group. Audit Trends 1995;3:127-31.

24 Webb SJ, Dowell AC, Heywood P. Survey of general practice audit in Leeds. BMF 1991;302:390-2.

25 Johnson R. Where have all the pennies gone? The work of Manchester medical audit advisory group. BMF 1994;309: 98-102.

26 Tabandeh H, Thompson GM. Auditing ophthalmology Audits. Eye 1995;9(suppl):1-5.

27 Watkins CJ, King J. Understanding the barriers to medical audit: insights from the experience of one practice. Audit Trends 1996;4:47-52.
28 Normand C, Ditch J, Dockrell J, et al. Clinical audit in professions allied to medicine and related therapy professions. Report to the Department of Health on a Pilot Study. Belfast: Health and Healthcare Research Unit, Queen's University Belfast, 1991.

29 Russell I, Addington-Hall J, Avery P, et al. Medical audit in general practice. I: effects on doctors' clinical behaviour for
common childhood conditions. BMf 1992;304:1480-4.

30 Pringle M, Bradley C, Carmichael C, et al. A survey of attitudes to and experience of medical audit in general practice: implications for MAAGS. Audit Trends 1994;2:913.

31 Cooper A, French D. Illustrative examples of successful audit in general practice. Audit Trends 1993;1:166-9.

32 Toy PTCY. Effectiveness of transfusion audits and practice guidelines. Arch Path Lab Med 1994;118:435-7.

33 Penney GC, Templeton A. Impact of a national audit project on gynaecologists in Scotland. Quality in Health Care 1995;4:37-9.

34 Sellu D. Time to audit audit. BMF 1996;312:128-9.

35 Foster J, Willmot M, Coles J. Evaluating audit. Nursing and therapy audit. An evaluation of twenty four projects and initatives. London: Caspe Research, 1996.

36 Webb MD, Harvey IM. Taking stock of medical audit: a questionnaire survey. Medical Audit News 1992;2:18.

37 McKenna HP. A multiprofessional approach to audit. Nursing Standard 1995;9:32-5.

38 Kerrison S, Packwood T, Buxton M. Medical audit. Taking stock. London: King's Fund Centre, 1993.

39 Smith HE, Russell GI, Frew AJ, et al. Medical audit: the differing perspectives of managers and clinicians. $f \mathrm{R}$ Coll Physicians Lond 1992;26:177-80.

40 Davison K, Smith L. Time spent by doctors on medical audit. Psych Bull 1993;17:418-19.

41 Lewis C, Combes D. Is general practice audit alive and well? The view from Portsmouth. Br F Gen Pract 1996;46: 735-6.

42 Barton A, Spencer J. Differences in attitudes towards audit among specialties in the Northern Region. Medical Audit News 1994;4:78-9.

43 Kinn SR, Smith PJ. Medical audit activity in primary and secondary care in the West of Scotland. Health Bull 1996;54:252-7.

44 Greenhalgh T. Audit. BMf 1992;305:961.

45 Sherwood T. Exitus auditus-no fun. Lancet 1992;340:378.

46 Farrell L. Audit my shorts. BMF 1995;311:1171.

47 Black N, Thompson E. Obstacles to medical audit: British doctors speak. Soc Sci Med 1993;36:849-56.

48 Firth-Cozens J, Storer D. Registrars' and senior registrars' perceptions of their audit activities. Quality in Health Care 1992;1:161-4

49 Gabbay J, McNicol MC, Spiby J, et al. What did audit achieve? Lessons from preliminary evaluation of a year's medical audit. BMF 1990;301:526-9.

50 Lough JRM, McKay J, Murray TS. Audit and summative assessment: two years' pilot experience. Med Educ 1995;29: 101-3.

51 Gabbay J, Layton AJ. Evaluation of audit of medical inpatient records in a district general hospital. Quality in Health Care 1992;1:43-7.

52 Lough JRM, McKay J, Murray TS. Audit: trainers' and trainees' attitudes and experiences. Med Educ 1995;29:8590

53 Karran SJ, Ranaboldo CJ, Karran A. Review of the perceptions of general surgical staff within the Wessex region of the status of quality assurance and surgical audit. Ann $R$ Coll Surg Engl 1993;75(suppl):104-7. 
54 Millard A. Perceptions of clinical audit: a preliminary evaluation. Fournal of Clinical Effectiveness 1996;1:96-9.

55 Robinson S. Evaluating the progress of clinical audit. The International fournal of Theory, Research and Practice 1996;2:373-92

56 Lord J, Littlejohns P. Development of an instrument to assess staff perceptions of the impact of trust-based clinical audit programmes. Fournal of Clinical Effectiveness 1996;1: 83-9.

57 Walshe K, Coles J. Evaluating audit. A review of initiatives. London: Caspe Research, 1993.

58 Buttery Y, Walshe K, Coles J, et al. The development of audit. Findings of a national survey of healthcare provider units in England. London: Caspe Research, 1994.

59 Buttery Y, Walshe K, Rumsey M, et al. Evaluating audit. Provider audit in England. A review of twenty-nine programmes. London: Caspe Research, 1995.

60 Amess M, Walshe K, Shaw C, et al. Evaluating audit. The audit activities of the medical Royal Colleges and their faculties in England. London: Caspe Research, 1995.

61 Walshe K, editor. The traits of success in clinical audit. Evaluating clinical audit: past lessons, future directions. London: The

62 Robinson S. Audit in the therapy professions: some Robinson S. Audit in the therapy professions: some
constraints on progress. Quality in Health Care 1996;5:20614.

63 Baker R, Robertson N, Farooqi A. Audit in general practice: factors influencing participation. BMF 1995;311:31-4.

64 Chambers R, Bowyer S, Campbell I. Audit activity and quality of completed audit projects in primary care in Staffordshire. Quality in Health Care 1995;4:178-83.

65 Davies C, Fletcher J, Wilmot J, et al. Co-ordinated audit in Warwickshire 1991-1993. Audit Trends 1995;3:121-6.

66 Millard A. Health professionals' needs: audit reports. Audit Trends 1996;4:129-32.

67 Webb MD, Harvey IM. Auditing the introduction of audit. Medical Audit News 1994;4:19-20.

68 Spencer JA. Audit and academic departments of general practice: a survey in the United Kingdom and Eire. $B r f$ Gen Pract $1992 \cdot 42 \cdot 333-5$.

69 Eccles MP, Deverill M, McColl E, et al. A national survey of audit activity across the primary-secondary care interface. Quality in Health Care 1996;5:193-200.

70 Lord J, Littlejohns P. Secret garden. Health Service fournal 1994;104:18-20.

71 Berger A. Why doesn't audit work? (editorial). BMF 1998;316:875-6.

72 Thomson R, Elcoat C, Pugh E. Clinical audit and the purchaser-provider interaction: different attitudes and $\mathrm{ex}-$ pectations in the United Kingdom. Quality in Health Care 1996;5:97-103.

73 Derry J, Lawrence M, Griew K, et al. Auditing audits: the method of Oxfordshire medical audit advisory group. BMF 1991;303:1247-9.

74 Walshe K, Coles J. Evaluating audit. Developing a framework. London: CASPE Research, 1993.

75 Crombie IK, Davies HTO. Towards good audit. Br f Hosp Med 1992;48:182-5.

76 Parker J, Barnes S. Auditing audits. BMF 1992;304:254.

77 Williams H, Beaton SA. Auditing audits. Qualty in Health Care 1992;1:206-7.

78 Walshe K. Opportunities for improving the practice of clinical audit. Quality in Health Care 1995;4:231-2.

79 Hearnshaw HM, Baker RH, Robertson N. Multidisciplinary audit in primary health care teams: facilitation by audit support staff. Quality in Health Care 1994;3:1648 .

80 Rumsey M, Buttery Y, Bennett J, et al. Wythenshawe hospital's clinical audit programme. A case study. London: CASPE Research, 1996

81 Bennett J, Coles J. Evaluating audit. Brighton health care NHS trust's clinical audit programme. A case study. London: Caspe Research, 1996.

82 Rumsey M, Buttery Y, Bennett J, et al. Evaluating audit. North Staffordshire's joint clinical audit programme. London: Caspe Research, 1996

83 Lervy B, Wareham K, Cheung WY. Practice characteristics associated with audit activity: a medical audit advisory group survey. Br f Gen Pract 1994;44:311-14.

84 Grol R, Wensing M. Implementation of quality assurance and medical audit: general practitioners' perceived obstaand medical audit: general practitioners' perceived obs
cles and requirements. $B r$ f Gen Pract 1995;45:548-52.

85 Reizenstein P. Quality and Health Care in Sweden 1991;303: 900-2.

86 Collopy B. Audit activities in Australia. BMF 1991;303: 1523-5.

87 Giraud A. Medical audit in France: historical perspective. BMF 1992;304:426-8.

88 Chassin M, Galvin R. The urgent need to improve health care quality. Institute of Medicine National Roundtable on Health Care Quality. FAMA 1998;280:1000-5.

89 Douglas C. Clinical governance made simple. $B M F$ 1998;317:287-8.

90 Goodman N. Sacred cows to the abbatoir. Clinical governance. BMf 1998;317:1725-7. 